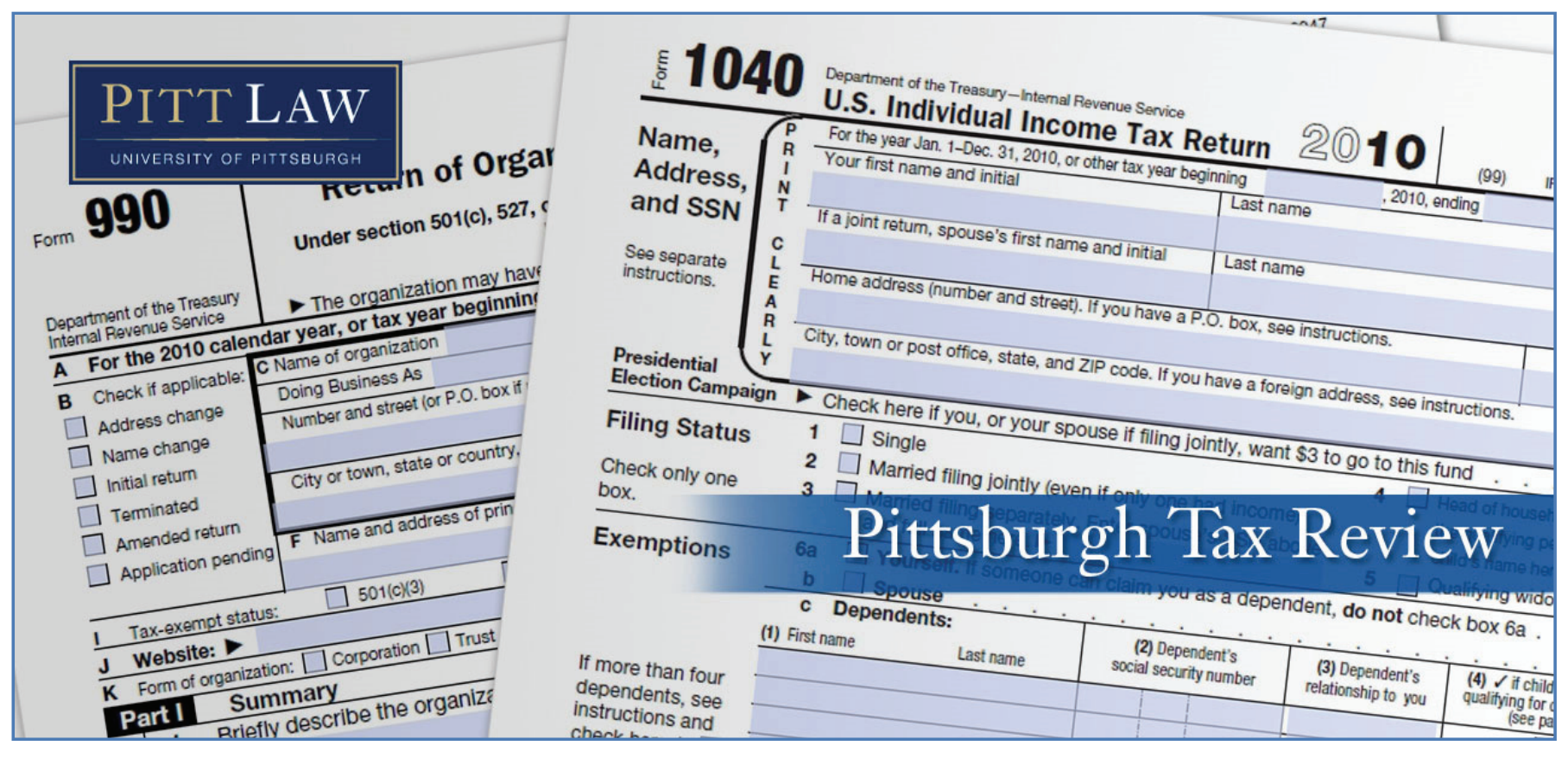

Volume 11 (2014) | ISSN 1932-1821 (print) 1932-1996 (online)

DOI 10.5195/taxreview.2014.26 | http://taxreview.law.pitt.edu

\title{
OFFICERS UNDER THE APPOINTMENTS CLAUSE
}

\author{
John T. Plecnik
}

\section{(c) BY-NC-ND}

This work is licensed under a Creative Commons Attribution-Noncommercial-No Derivative Works 3.0 United States License.

\section{ULIS D-Serle}

This journal is published by the University Library System of the University of Pittsburgh as part of its D-Scribe Digital Publishing Program, and is cosponsored by the University of Pittsburgh Press. 


\title{
OFFICERS UNDER THE APPOINTMENTS CLAUSE
}

\author{
John T. Plecnik ${ }^{*}$
}

\section{INTRODUCTION}

The year is 1957 and you are Ronald Dworkin, ${ }^{1}$ law clerk to Judge Learned Hand of the U.S. Court of Appeals for the Second Circuit. Both you and Judge Hand spend the majority of your time performing legal research and writing court opinions - an important task by any measure. However, from that point on, the natures of your respective positions diverge. Judge Hand was appointed by President Calvin Coolidge and confirmed by the Senate. You were hired by the Judge after a brief interview in between classes at Harvard Law. Judge Hand renders final appellate court decisions on life and death issues. Any decision you author, however insignificant, is subject to the Judge's supervision and approval. Although a law clerk does the work of a judge, a law clerk is not a judge. Therefore, it is hardly surprising to learn that an Article III judge is an Officer of the United States, who must be selected pursuant to the special procedures of the Appointments Clause, whereas a law clerk is a mere employee, who may be hired by anyone in any manner. Even absent a legal

\footnotetext{
* Assistant Professor of Law, Cleveland-Marshall College of Law, Cleveland State University. B.A., Belmont Abbey College, 2003; J.D., Duke University School of Law, 2006; LL.M. in Taxation, New York University School of Law, 2009. I thank the participants of the 2013 Pittsburgh Tax Workshop, including Judge Mark Holmes of the U.S. Tax Court, Danshera Cords, Charlotte Crane, Michelle Drumbl, Heather Field, William Foster, Andy Grewal, David Herzig, Kristin Hickman, Steve Johnson, Leandra Lederman, Shannon McCormack, and Shu-Yi Oei. In particular, I thank the Workshop's organizer, Mirit Eyal-Cohen. I am also grateful to my colleagues David Forte, Browne Lewis, and James Wilson for helpful discussions on the subject matter of this Article. Lastly, I thank the editors of the Pittsburgh Tax Review, especially Saheli Chakrabarty. Any errors in this Article are my own, and the conclusions do not necessarily represent the views of any other individual.

${ }^{1}$ Judge Learned Hand famously referred to Professor Ronald Dworkin "as the best law clerk he ever had." In Memoriam, Ronald Dworkin, NYU LAw (Feb. 14, 2013), https://www.law.nyu.edu/news/ RONALD_DWORKIN_MEMORIAM. Throughout his distinguished career, Professor Dworkin taught at Yale, Oxford, and NYU, and was one of the most cited legal scholars of the twentieth century. Fred R. Shapiro, The Most-Cited Legal Scholars, 29 J. LegAL STUD. S1 (2000). Professor Dworkin passed away on February 14, 2013.
}

Pitt Tax Review | ISSN 1932-1821 (print) 1932-1996 (online)

DOI 10.5195/taxreview.2014.26 | http://taxreview.law.pitt.edu 
standard, the answer is almost intuitive in this stark case. However, the dividing line between an Officer and employee is not always so clear.

After clerking, you join Sullivan \& Cromwell in New York to pay off your student loans and make the down payment on your first home. Thereafter, you enter the professoriate at Yale Law and start writing lengthy symposium pieces on political philosophy. In the years that follow, three of your former colleagues at Sullivan also leave Big Law, but decide on government service instead. One successfully applies to the U.S. Tax Court to serve as a special trial judge. ${ }^{2}$ Another sits for the ALJ exam and is selected as an administrative law judge by the Federal Deposit Insurance Corporation. ${ }^{3}$ A third joins the Internal Revenue Service as an appeals officer. ${ }^{4}$ Each one of these positions serves an adjudicative function and is imbued with a degree of authority. However, none of them are entirely free from supervision by higher-ranking judges or officials. Your friends' authority falls somewhere in the gray area between an Article III judge and a law clerk-between what clearly constitutes an Officer versus a mere employee. In these closer cases, intuition alone is not enough to draw the line. A precise definition of what constitutes an Officer is necessary to make the finer distinctions.

Much ink has been spilled, and many keyboards worn, debating the definition of "Officers of the United States" under the Appointments Clause of Article II, Section 2, Clause 2 of the U.S. Constitution. Most recently, this debate has focused on the denizens of the Office of Appeals of the Internal Revenue Service (IRS). In Tucker I, the U.S. Tax Court faced the

${ }^{2}$ The chief judge of the U.S. Tax Court has the authority to appoint special trial judges. I.R.C. $\S 7443 \mathrm{~A}(\mathrm{a})$.

${ }^{3}$ To qualify for selection as an administrative law judge for any federal agency, an applicant must be licensed to practice law, possess seven years of trial or hearing experience, and pass the "administrative law judge competitive examination" administered by the U.S. Office of Personnel Management. Classification Qualifications, US OfFice of Personnel MANAgement, http://www .opm.gov/policy-data-oversight/classification-qualifications/general-schedule-qualification-standards/ specialty-areas/administrative-law-judge-positions/. This examination is best known as the ALJ exam.

${ }^{4}$ The Commissioner of the Internal Revenue Service hires appeals officers and all personnel within the Office of Appeals pursuant to her general hiring authority. I.R.C. § 7804(a) ("Unless otherwise prescribed by the Secretary, the Commissioner of Internal Revenue is authorized to employ such number of persons as the Commissioner deems proper for the administration and enforcement of the internal revenue laws ...."); see also Tucker v. Comm'r, 135 T.C. 114, 135 (2010) ("the Office of Appeals exists pursuant to section 7804(a)").

Pitt Tax Review | ISSN 1932-1821 (print) 1932-1996 (online) DOI 10.5195/taxreview.2014.26 | http://taxreview.law.pitt.edu 
question of whether the settlement officers, appeals officers, and appeals team managers (collectively, IRS hearing officers) within the Office of Appeals are Officers or mere employees. ${ }^{5}$ In Tucker II, the U.S. Court of Appeals for the District of Columbia Circuit (D.C. Circuit) faced the same question on appeal. ${ }^{6}$ Both courts sided with the IRS in holding that none of the above are Officers. Although it hardly seems controversial to agree with the Tax Court and D.C. Circuit when the U.S. Supreme Court denies certiorari in the case, ${ }^{7}$ remarkably, all previous scholarship disputes the outcome of the Tucker decisions. ${ }^{8}$ This Article will defend that outcome as a proper application of Supreme Court precedent.

The distinction between Officers and employees is constitutionally and practically significant, because the former must be appointed by the President, with or without the advice and consent of the Senate, Courts of Law, or Heads of Departments. ${ }^{9}$ In contrast, employees may be hired by any arm of government. For obvious reasons, only a small minority of government officials are appointed. The vast majority are hired as employees. As in the Tucker decisions, Appointments Clause controversies are generally triggered when a government official who was hired as an employee is accused of unconstitutionally wielding the more significant authority of an Officer. If the accusation is proved, then the government official was acting ultra vires and every decision the official made is presumptively invalid and subject to collateral attack. ${ }^{10}$

\footnotetext{
${ }^{5}$ Tucker v. Comm'r, 135 T.C. 114 (2010).

${ }^{6}$ Tucker v. Comm'r, 676 F.3d 1129 (D.C. Cir. 2012), cert. denied, 133 S. Ct. 646 (2012).

${ }^{7}$ Tucker v. Comm'r, 133 S. Ct. 646 (U.S. 2012). In addition, the Tax Court and D.C. Circuit recently reaffirmed the Tucker decisions. See Byers v. Comm'r, 103 T.C.M. (CCH) 1168 (2012) (citing Tucker with approval), aff'd, Byers v. Comm'r, 2014 U.S. App. LEXIS 933 (D.C. Cir. Jan. 17, 2014).

${ }^{8}$ See, e.g., Stacy M. Lindstedt, Developing the Duffy Defect: Identifying Which Government Workers Are Constitutionally Required to Be Appointed, 76 Mo. L. Rev. 1143 (2011); Carlton M. Smith, Does Collection Due Process Violate the Appointments Clause?, 126 TAX NOTES 777 (2010); Carlton M. Smith, Does the Failure to Appoint Collection Due Process Hearing Officers Violate the Constitution's Appointments Clause?, 10 J. TAX PRAC. \& PROC. 35, 42 (2008).

${ }^{9}$ U.S. CONST. art. II, § 2, cl. 2.

${ }^{10}$ See, e.g., Freytag v. Comm'r, 501 U.S. 868, 879 (1991) (noting that the Appointments Clause "challenge goes to the validity of the Tax Court proceeding").
}

Pitt Tax Review | ISSN 1932-1821 (print) 1932-1996 (online) DOI 10.5195/taxreview.2014.26 | http://taxreview.law.pitt.edu 
The entire text of the Appointments Clause is brief, leaving case law to fill in the blanks. To date, virtually every court and commentator begins their analysis by conceding that the case law, and hence, the doctrine of the Appointments Clause is unclear. Unfortunately, this lack of clarity has resulted in a sort of constitutional Rorschach test for who is an Officer, giving some comfort to both sides in nearly every case. The usual mode for deciding an Appointments Clause case was comparative-courts would analogize the position at issue to similar positions in other cases. ${ }^{11}$ No more. This Article submits that subsequent to the seminal Tucker decisions, the black letter law for distinguishing between Officer and employee is close to fully developed.

This Article is the first to comprehensively outline the post-Tucker doctrine of the Appointments Clause. Consequently, it is the first to state the post-Tucker definition of Officer. Under Tucker I, an Officer under the Appointments Clause holds a position that is (1) "established by Law," (2) "continuing," and (3) vested with "significant authority."12 Under Tucker II, "significant authority" consists of (1) power over "significant" or important matters, (2) "discretion," and (3) "final" decision-making authority. ${ }^{13}$

Looking back to the opening hypothetical, we intuit that a law clerk is a lesser functionary or mere employee, ${ }^{14}$ and from case law, we know the status of special trial judges, ${ }^{15}$ administrative law judges (ALJs) of the Federal Deposit Insurance Corporation (FDIC), ${ }^{16}$ and IRS appeals

${ }^{11}$ Tucker, 135 T.C. at 162 ("The Supreme Court has yet to fully define the term 'significant authority'; and 'ascertaining the test's real meaning requires a look at the roles of the employees whose status was at issue in other cases."') (quoting Landry v. FDIC, 204 F.3d 1125, 1133 (D.C. Cir. 2000)).

${ }^{12}$ Tucker, 135 T.C. at $152-65$.

${ }^{13}$ Tucker v. Comm'r, 676 F.3d 1129, 1132 (D.C. Cir. 2012).

${ }^{14}$ Under this Article's interpretation of the Tucker tests, a law clerk is demonstrably not an Officer. A law clerk's position is (1) "established by Law," because it is lawful; and (2) "continuing," because it is full-time and indefinite; but lacks (3) "significant authority." Although the position has (1) power over "significant" or important matters, it lacks (2) discretion and (3) final decision-making authority, because a judge supervises and approves all of a law clerk's work.

${ }^{15}$ Freytag, 501 U.S. at 881 ("We agree with the Tax Court and the Second Circuit that a special trial judge is an 'inferior Officer' whose appointment must conform to the Appointments Clause.").

${ }^{16}$ Landry, 204 F.3d at 1134 (“As the ALJs ... have no [final decision-making authority], we conclude that they are not inferior officers.").

Pitt Tax Review | ISSN 1932-1821 (print) 1932-1996 (online) DOI 10.5195/taxreview.2014.26 | http://taxreview.law.pitt.edu 
officers. ${ }^{17}$ In Freytag v. Commissioner, the U.S. Supreme Court held that special trial judges are Officers, ${ }^{18}$ whereas the D.C. Circuit held that FDIC ALJs and IRS appeals officers are mere employees in Landry v. FDIC ${ }^{19}$ and Tucker II, ${ }^{20}$ respectively. The more interesting question is why. This Article submits that the Tucker decisions answer this question with their tripartite tests for Officer and "significant authority." In fact, this Article posits that the outcome of every modern Appointments Clause case, dating back to Buckley v. Valeo, ${ }^{21}$ is explicable through this doctrine.

In Part II, this Article will describe the meaning and purpose of the Appointments Clause. In Part III, this Article will briefly outline the early precedent and the seminal case of Buckley v. Valeo. $^{22}$ Lastly, Part IV explains the Tucker decisions ${ }^{23}$ in light of the Constitution, previous precedent, and status quo bias. It also delineates the current definition of Officer.

\section{MEANING AND PURPoSE OF THE APPOINTMENTS ClAuSE}

\section{A. Meaning of the Appointments Clause}

The text of the Appointments Clause is set forth in Article II, Section 2, Clause 2 of the U.S. Constitution and provides for the appointment of "Officers of the United States":

[The President] shall nominate, and by and with the Advice and Consent of the Senate, shall appoint Ambassadors, other public Ministers and Consuls, Judges of the Supreme Court, and all other Officers of the United States, whose

${ }^{17}$ Tucker, 135 T.C. at 165 ("Since [FDIC ALJs are not Officers] the lesser position of CDP 'appeals officer' [is not an Officer]"); Tucker, 676 F.3d at 1135 ("we find even Appeals employees' authority over tax liability insufficient to rank them as inferior Officers").

${ }^{18}$ Freytag, 501 U.S. at 881.

${ }^{19}$ Landry, 204 F.3d at 1134.

${ }^{20}$ Tucker, 676 F.3d at 1135 .

${ }^{21}$ See generally Buckley v. Valeo, 424 U.S. 1 (1976); see also Lindstedt, supra note 8, at 1151 ("Current Appointments Clause discussions generally date back only to 1976.").

${ }^{22}$ Buckley, 424 U.S. 1.

${ }^{23}$ Tucker, 135 T.C. at 165; Tucker, 676 F.3d at 1135.

Pitt Tax Review | ISSN 1932-1821 (print) 1932-1996 (online) DOI 10.5195/taxreview.2014.26 | http://taxreview.law.pitt.edu 


\section{6 |Pittsburgh Tax Review | Vol. 112014}

Appointments are not herein otherwise provided for, and which shall be established by Law: but the Congress may by Law vest the Appointment of such inferior Officers, as they think proper, in the President alone, in the Courts of Law, or in the Heads of Departments. ${ }^{24}$

This text-coupled with other provisions in the Constitution as well as Supreme Court precedent-allows us to draw three uncontroversial conclusions as to its meaning.

\section{Four Modes of Selection under the Appointments Clause}

The Appointments Clause requires all "Officers" to be appointed by one of four modes: (1) by the President with Senate confirmation, (2) by the President alone, (3) by the Courts of Law, and (4) by the Heads of Departments. ${ }^{25}$ Although the first two modes require little or no explanation, it should be noted that the Supreme Court has held that the term "Courts of Law" is not limited to Article III courts and includes Article I legislative courts such as the U.S. Tax Court. ${ }^{26}$ It should also be noted that a Department is defined as a "'free-standing, self-contained entity in the Executive Branch," such as the Department of the Treasury. ${ }^{27}$ It refers to "executive divisions like the Cabinet-level departments . . .." 28 "Accordingly, the term 'Heads of Departments' does not embrace 'inferior commissioners and bureau officers" who head up sub-departments and agencies within Departments such as the IRS. ${ }^{29}$ Therefore, the Secretary of the Treasury is a Department Head who may constitutionally appoint "inferior Officers" with statutory permission, whereas the Commissioner of the IRS is not.

\footnotetext{
${ }^{24}$ U.S. CONST. art. II, § 2, cl. 2.

${ }^{25} \mathrm{Id}$.

${ }^{26}$ Freytag, 501 U.S. at 888-92 ("an Article I court, which exercises judicial power, can be a 'Court of Law' within the meaning of the Appointments Clause").

${ }^{27}$ Free Enter. Fund v. Pub. Co. Accounting Oversight Bd., 130 S. Ct. 3138 (2010) (quoting Freytag, 501 U.S. at 915 (Scalia, J., concurring in part and concurring in judgment)).

${ }^{28}$ Freytag, 501 U.S. at 886.

${ }^{29}$ Id. (citing United States v. Germaine, 99 U.S. 508, 511 (1878)). The IRS is an agency within the Treasury Department. Loving v. IRS, 742 F.3d 1013, 1015 (D.C. Cir. 2014) ("the IRS, a subordinate agency within the Treasury Department").
}

Pitt Tax Review | ISSN 1932-1821 (print) 1932-1996 (online) DOI 10.5195/taxreview.2014.26 | http://taxreview.law.pitt.edu 


\section{Officer v. Employee}

The Appointments Clause distinguishes between Officers, who must be appointed, and mere employees, who may be hired by anyone in any manner. This is an implicit distinction, because the Appointments Clause never utilizes the term "employee," let alone juxtaposes that term against an Officer. However, the Supreme Court has held that the term Officer "does not include all employees of the United States ...."30 Furthermore, it has defined the term "employee" to mean "lesser functionaries subordinate to officers of the United States."

Lastly, the Tax Court has recently held that "the Appointments Clause governs appointment of individual persons," not groups. ${ }^{32}$ The appropriate inquiry is whether a single position possesses the necessary characteristics of an Office, not whether several positions might collectively constitute an Office. $^{33}$

\section{Principal v. Inferior Officer}

The Appointments Clause distinguishes between "principal Officers," 34 who must be appointed by the President with Senate confirmation, and "inferior Officers," who may be appointed by the President alone, Courts of Law, or Heads of Departments if Congress permits by statute. ${ }^{35}$ Without statutory permission, "inferior Officers" must

\footnotetext{
${ }^{30}$ Buckley, 424 U.S. at 126 (citing Auffmordt v. Hedden, 137 U.S. 310, 327 (1890); Germaine,
} 99 U.S. at 511).

${ }^{31} \mathrm{Id}$.

32 Byers v. Comm'r, 103 T.C.M. (CCH) 1168 (2012) ("the Appointments Clause governs appointment of individual persons as 'officers of the United States.' It does not apply to a group of individuals who collectively constitute an office.") (citing Buckley, 424 U.S. at 126; Germaine, 99 U.S. at 510).

${ }^{33} \mathrm{Id}$.

34 'The term 'principal officer' is not in the Appointments Clause but is borrowed from the immediately preceding clause (i.e., U.S. CONST. art. II, sec. 2, cl. 1), which provides that 'The President $* * *$ may require the Opinion in writing, of the principal Officer in each of the executive Departments, upon any Subject relating to the Duties of their respective Offices." Tucker, 135 T.C. at 122.

${ }^{35}$ In the so-called "Excepting Clause," the Appointments Clause provides that "the Congress may by Law vest the Appointment of such inferior Officers, as they think proper, in the President alone, in the Courts of Law, or in the Heads of Departments.... [I]ts obvious purpose is administrative convenience ...." Edmond v. United States, 520 U.S. 651, 660 (1997) (citing Germaine, 99 U.S. at

Pitt Tax Review | ISSN 1932-1821 (print) 1932-1996 (online) DOI 10.5195/taxreview.2014.26 | http://taxreview.law.pitt.edu 
be appointed by the President with Senate confirmation just like "principal Officers." 36

"The line between 'inferior' and 'principal' officers is one that is far from clear, and the Framers provided little guidance into where it should be drawn." ${ }^{37}$ However, the U.S. Supreme Court has held that the distinction between inferior and principal Officers is not so much about their rank or responsibility, but whether the Officer in question has a superior. ${ }^{38}$ An Officer who answers directly to the President is a "principal Officer," whereas an Officer who answers to yet another Officer is an "inferior Officer." 39 One significant factor in determining whether one Officer is answerable to another is whether that Officer may be removed by the other at will and without cause. ${ }^{40}$

\section{B. Purpose of the Appointments Clause}

"[T]he Appointments Clause of Article II is more than a matter of 'etiquette or protocol'; it is among the significant structural safeguards of the constitutional scheme."41 Specifically, the Founders authored the Appointments Clause as a safeguard for the separation of powers. ${ }^{42}$ To that end, "[t]he Appointments Clause has four related but distinct purposes."

510). However, "that convenience was deemed to outweigh the benefits of the more cumbersome procedure [of appointment by the President with Senate confirmation] only with respect to the appointment of "inferior Officers." $I d$.

${ }^{36}$ See U.S. CONST. art. II, § 2, cl. 2; Tucker, 135 T.C. at 125-26 ("while the Appointments Clause does allow an exception for inferior officers to be appointed by the President alone or by the Secretary, the terms of that exception are that 'Congress may by Law vest the Appointment' in the President alone or the Head of a Department. Where Congress has not made any such exception 'by Law,' then the default rule applies.").

${ }^{37}$ Morrison v. Olson, 487 U.S. 654, 671 (1988).

${ }^{38} I d$.

${ }^{39} I d$.

${ }^{40}$ Free Enter. Fund, 130 S. Ct. at 3162 ("In particular, we noted that "[t]he power to remove officers' at will and without cause 'is a powerful tool for control' of an inferior." (quoting Edmond, 520 U.S. at 665)).

${ }^{41}$ Edmond, 520 U.S. at 659.

${ }^{42}$ The Supreme Court has stated "that we must examine the language of Art. II, § 2, cl. 2" in the context of separation of the powers. Buckley, 424 U.S. at 124-25. It has also acknowledged that " $[\mathrm{t}] \mathrm{he}$

Pitt Tax Review | ISSN 1932-1821 (print) 1932-1996 (online)

DOI 10.5195/taxreview.2014.26 | http://taxreview.law.pitt.edu 
1. Prevent One Branch From Creating and Filling the Same Office

First and foremost, the Appointments Clause was intended to guard against one branch of government both creating and filling the same government office. ${ }^{44}$ This concern arose in direct response to the colonial practice of King George III, who "erected a multitude of New Offices, and sent hither swarms of Officers to harass our people and eat out their substance." ${ }^{45}$ At the time, this practice of creating and filling the same government office was considered "the most insidious and powerful weapon of eighteenth century despotism." 46 Under the Appointments Clause, no one branch of government is king. ${ }^{47}$ Generally, the legislative branch creates the position of Officer, and the executive or judicial branch must fill it. ${ }^{48}$

\section{Prevent Diffusion of the Appointment Power}

The Appointments Clause guards against "the diffusion of the appointment power" in the executive branch by prohibiting Congress from granting that power to lower-level officials. ${ }^{49}$ Only the President, or one appointed by the President, may appoint an "Officer." ${ }^{, 0}$ Stated otherwise, the Appointments Clause allows "only one degree of separation between any duly appointed officer and the President, thus maintaining the locus of executive power in the President himself."

\footnotetext{
roots of the separation-of-powers concept embedded in the Appointments Clause are structural and political." Freytag, 501 U.S. at 878.

${ }^{43}$ Tucker, 135 T.C. at 120.

${ }^{44} \mathrm{Id}$.

${ }^{45}$ The DeClaration of IndePendence para. 12 (U.S. 1776).

${ }^{46}$ George S. Wood, The Creation of the American Republic 1776-1787, at 143 (1969).

${ }^{47}$ See Tucker, 135 T.C. at 120 .

${ }^{48}$ See Edmond, 520 U.S. at 659 ("By vesting the President with the exclusive power to select the principal (noninferior) officers of the United States, the Appointments Clause prevents congressional encroachment upon the Executive and Judicial Branches.").

${ }^{49}$ Tucker, 135 T.C. at $120-21$.

${ }^{50} \mathrm{Id}$.

${ }^{51} I d$.
}

Pitt Tax Review | ISSN 1932-1821 (print) 1932-1996 (online) DOI 10.5195/taxreview.2014.26 | http://taxreview.law.pitt.edu 


\section{0 |Pittsburgh Tax Review | Vol. 112014}

\section{Political Accountability}

By preventing "diffusion," the Founders also endeavored to ensure political accountability. ${ }^{52}$ By guaranteeing only one degree of separation between the President and her Officers, the President cannot avoid responsibility for the actions of her Officers. ${ }^{53}$ As Alexander Hamilton noted, "The blame of a bad nomination would fall upon the president singly and absolutely." 54 In addition, as James Madison noted, by maintaining a proximity between the President and her Officers, even unelected appointees are "the choice, though a remote choice, of the people themselves." 55

\section{More Qualified Officers}

By vesting the bulk of the appointment power in the President rather than Congress, the Founders hoped to "assure a higher quality of appointments." 56 specifically, they hoped "that the President would be less vulnerable to interest-group pressure and personal favoritism than would a collective body. 'The sole and undivided responsibility of one man will naturally beget a livelier sense of duty, and a more exact regard to reputation.","57

\section{APPOINTMENTS CLAUSE JURISPRUDENCE}

The law of the Appointments Clause derives first from Article II, Section 2, Clause 2 of the U.S. Constitution, and second from a long line of Supreme Court precedent that authoritatively interprets the Clause. However, in recent years, an opinion authored by the Office of Legal Counsel of the Department of Justice (the "OLC") has been cited with increasing frequency by scholars and the federal courts, including the

\footnotetext{
${ }^{52} I d$. at 121.

${ }^{53} \mathrm{Id}$.

${ }^{54}$ THE Federalist No. 77 (Alexander Hamilton).

${ }^{55}$ The Federalist No. 39 (James Madison).

${ }^{56}$ Edmond, 520 U.S. at 659 (quoting THE FEDERALIST No. 76 (Alexander Hamilton)).

${ }^{57} \mathrm{Id}$.
}

Pitt Tax Review | ISSN 1932-1821 (print) 1932-1996 (online) DOI 10.5195/taxreview.2014.26 | http://taxreview.law.pitt.edu 
Supreme Court. ${ }^{58}$ The OLC is a core of government attorneys and describes itself as "outside counsel for the other agencies of the Executive Branch.",59 Although opinions authored by the OLC are not binding precedent like a court opinion, they are extremely persuasive as the expert position of the government agency tasked with "providing legal advice to the Executive Branch on all constitutional questions."

The opinion at issue is entitled "Officers of the United States within the Meaning of the Appointments Clause." In line with the Supreme Court's choice of parlance, this Article will hereinafter refer to this opinion as the "OLC Memo." ${ }^{\prime \prime 1}$ The OLC Memo reads like a treatise and gives a comprehensive outline of Appointments Clause jurisprudence from the nation's founding through its publication date on April 16, 2007. Although the courts have disagreed with the OLC Memo in several significant respects, ${ }^{62}$ it is impossible to objectively discuss recent case law without acknowledging its influence.

\section{A. Definition of Officer Under Early Case Law}

In several of the earliest cases, the courts used "circular logic" to define the constitutional term of Officer. ${ }^{63}$ Namely, if a position was filled pursuant to the Appointments Clause, then the courts held that the position is an Office and must be appointed. ${ }^{64}$ If a position is not appointed, then

${ }^{58}$ See, e.g., Free Enter. Fund, 130 S. Ct. at 3178.

59 The United States Department of Justice Office of Legal Counsel, http://www .justice.gov/olc/.

${ }^{60} \mathrm{Id}$.

${ }^{61}$ Free Enter. Fund, 130 S. Ct. at 3178.

${ }^{62}$ Most significantly, the OLC Memo claims that "discretion" is merely an "[a]rguably [r]elevant [c]haracteristic[]" and not "necessary" for significant authority. Memorandum Opinion for the General Counsels of the Executive Branch, 31 Op. O.L.C. 1, 17 (2007). This directly contrasts with Tucker II, in which the D.C. Circuit held that "the lack of discretion is determinative. ..." Tucker, 676 F.3d at 1134.

${ }^{63}$ Landry, 204 F.3d at 1132-33 ("“T]he earliest Appointments Clause cases often employed circular logic, granting officer status to an official based in part upon his appointment by the head of a department.").

${ }^{64}$ See, e.g., United States v. Mouat, 124 U.S. 303, 307 (1888) ("Unless a person in the service of the Government, therefore holds his place by virtue of an appointment by the President, or of one of the

Pitt Tax Review | ISSN 1932-1821 (print) 1932-1996 (online) DOI 10.5195/taxreview.2014.26 | http://taxreview.law.pitt.edu 


\section{2 |Pittsburgh Tax Review | Vol. 112014}

conveniently enough, the position is not an Office. ${ }^{65}$ However, even in the primordial days of the nation's founding, there was a rough consensus that a position is an Office if its holder is "delegated sovereign authority." 66 English common law and colonial era law dictionaries agreed that any person "charged" or "delegated" the sovereign authority of the government to intervene in others' affairs without their consent is an Officer. ${ }^{67}$ The OLC Memo posits that this early conception of sovereign authority is the forerunner of "significant authority" in Buckley v. Valeo. ${ }^{68}$

\section{B. Buckley v. Valeo and Modern Appointments Clause Jurisprudence}

Modern Appointments Clause jurisprudence dates back to Buckley $v$. Valeo, ${ }^{69}$ wherein the Supreme Court held that a position vested with "significant authority" constitutes an Office:

We think that the term "Officers of the United States" as used in Art. II, defined to include "all persons who can be said to hold an office under the government" in United States v. Germaine, supra, is a term intended to have substantive meaning. We think its fair import is that any appointee exercising significant authority pursuant to the laws of the United States is an "Officer of the United States," and must, therefore, be appointed in the manner prescribed by $\S 2$, cl. 2 , of that Article. ${ }^{70}$

In Buckley v. Valeo, the Supreme Court reviewed the appointment and powers of the eight-member Federal Election Commission (FEC) ${ }^{71}$

courts of justice or heads of Departments authorized by law to make such an appointment, he is not, strictly speaking, an officer of the United States.").

${ }^{65} I d$. (2007).

${ }^{66}$ Memorandum Opinion for the General Counsels of the Executive Branch, 31 Op. O.L.C. 1, 8

${ }^{67}$ Id. (citing King v. Burnell, (1700) 90 Eng. Rep. 478 (K.B.)); GILES JaCOB, A New LAW Dictionary (9th ed. 1772); T. CunNingham, 2 A New and Complete Law Dictionary (2d ed. 1771); MATthew BACON, 3 A NeW ABRIDGMENT OF THE LAW (4th ed. 1778).

${ }^{68}$ Memorandum Opinion for the General Counsels of the Executive Branch, 31 Op. O.L.C. 1, 11 12 (2007).

${ }^{69}$ See, e.g., Lindstedt, supra note 8, at 1151.

${ }^{70}$ Buckley, 424 U.S. at 125-26.

${ }^{71}$ Id. at $137-41$.

Pitt Tax Review | ISSN 1932-1821 (print) 1932-1996 (online) DOI 10.5195/taxreview.2014.26 | http://taxreview.law.pitt.edu 
established under the Federal Election Campaign Act of $1971^{72}$ and the Federal Election Campaign Act Amendments of $1974 .{ }^{73}$ The Secretary of the U.S. Senate and the Clerk of the U.S. House of Representatives were to serve as nonvoting, ex-officio members. ${ }^{74}$ The other six appointees were full voting members, two of which were appointed by the President, two by the President pro tempore of the Senate, and two by the Speaker of the House. $^{75}$ The appointments of all six voting members were subject to confirmation by both the Senate and House. ${ }^{76}$ Since none of the voting members were selected pursuant to the Appointments Clause, the Supreme Court held that none of them may constitutionally exercise significant authority. ${ }^{77}$

The Supreme Court then reviewed the powers of the voting members and sorted them into three categories: (1) investigative and informative powers- "functions relating to the flow of necessary information-receipt, dissemination, and investigation"; (2) interpretive and rulemaking powers - "functions with respect to the Commission's task of fleshing out the statute-rulemaking and advisory opinions"; and (3) enforcement powers- - functions necessary to ensure compliance with the statute and rules - informal procedures, administrative determinations and hearings, and civil suits." 78 The Supreme Court held "there can be no question that" Congress could delegate the "investigative and informative" powers to the unappointed voting members, because it could delegate those same powers to its own committees. ${ }^{79}$ However, it reached a different conclusion in

${ }^{72}$ Federal Election Campaign Act of 1971, Pub. L. No. 92-225, 86 Stat. 3.

${ }^{73}$ Federal Election Campaign Act of 1974, Pub. L. No. 93-443, 88 Stat. 1263.

${ }^{74}$ Buckley, 424 U.S. at 113.

${ }^{75} \mathrm{Id}$.

${ }^{76} \mathrm{Id}$.

${ }^{77}$ Even the two voting members appointed by the President were not selected pursuant to the Appointments Clause because their appointment was subject to confirmation by both the Senate and House. Under the Clause, Presidential appointments must be made by the President alone or by the President with confirmation by the Senate alone, not by the Senate and the House. See U.S. CONST. art. II, § 2, cl. 2.

${ }^{78}$ Buckley, 424 U.S. at 137.

${ }^{79}$ Id.

Pitt Tax Review | ISSN 1932-1821 (print) 1932-1996 (online) DOI 10.5195/taxreview.2014.26 | http://taxreview.law.pitt.edu 


\section{4 | Pittsburgh Tax Review | Vol. 112014}

considering "the more substantial powers" of the voting members. ${ }^{80}$ The Supreme Court held that only an Officer could exercise the interpretive and rulemaking powers because they were exercised "free from day to day supervision," and thus, constituted "a significant governmental duty exercised pursuant to a public law." 81 The Supreme Court also held that only an Officer could exercise the enforcement powers because they belonged to the executive branch. ${ }^{82}$

In short, we can distill the following legal principles from Buckley $v$. Valeo. First, Buckley coined the term "significant authority" and established the principle that only Officers may constitutionally wield such authority. ${ }^{83}$ Second, purely investigative and informative powers do not constitute significant authority. ${ }^{84}$ Third, "significant" interpretive and rulemaking powers, such as the power to issue regulations or make determinations without supervision, or "significant" enforcement powers, such as the power to bring suit to enforce a federal statute, constitute "significant authority." $" 85$ Fourth, one factor in determining whether authority is "significant" in nature is whether such authority is exercised "free from day-to-day supervision." 86 This last principle was reaffirmed by Freytag, in which the Supreme Court cited to the "independent authority" of special trial judges to make final decisions in holding them to be Officers. ${ }^{87}$

\footnotetext{
${ }^{80} I d$. at 138.

${ }^{81}$ Id. at $140-41$.

${ }^{82}$ Id. at $138-39$.

${ }^{83} \mathrm{Id}$. at $125-26$.

${ }^{84} \mathrm{Id}$. at 137.

${ }^{85}$ Id. at $138-41$.

${ }^{86} \mathrm{Id}$. at 140.

${ }^{87}$ Freytag, 501 U.S. at 882.
}

Pitt Tax Review | ISSN 1932-1821 (print) 1932-1996 (online) DOI 10.5195/taxreview.2014.26 | http://taxreview.law.pitt.edu 


\section{The "Duffy Defect"}

The so-called "Duffy Defect" is named for Professor John F. Duffy ${ }^{88}$ and refers to Appointments Clause violations. ${ }^{89}$ Although the Appointments Clause is as old as the Constitution itself, Professor Duffy's work sparked a renewed interest in the Clause. In particular, his famous assertion that administrative patent judges are Officers not only changed the manner in which those judges are appointed, but sparked a flurry of articles and lawsuits with respect to other positions. As a result, scholars and commentators often refer to an Appointments Clause or "triple 2" violation as the "Duffy Defect."

To use the popular term in a sentence, the failure to properly appoint an Officer in accordance with the special procedures of the Appointments Clause is a "Duffy Defect" in that appointment. As the Supreme Court concluded in Buckley v. Valeo, only properly appointed Officers may constitutionally wield "significant authority." 90 The decisions of a defectively appointed Officer are presumptively invalid and subject to collateral attack. As a result, the discovery of a potential "Duffy Defect" has significant and practical consequences.

The term "Duffy Defect" was coined shortly after Professor Duffy published a brief article on July 23, 2007, ${ }^{91}$ on the appointment of administrative patent judges for the Board of Patent Appeals and Interferences under the Intellectual Property and Communications Omnibus Reform Act of $1999 .{ }^{92}$ Prior to the 1999 Act, those judges were appointed by the Secretary of Commerce, who is unquestionably a Department Head

\footnotetext{
${ }^{88}$ Professor Duffy taught at the George Washington University Law School at the time he published his blog and law review articles entitled "Are Administrative Patent Judges Unconstitutional?" As of the date of this article, he teaches at the University of Virginia School of Law.

${ }^{89}$ See supra note 77 and accompanying text.

${ }^{90}$ Buckley, 424 U.S. at 138-39 (explaining that only Officers may wield significant authority).

${ }_{91}$ John F. Duffy, Are Administrative Patent Judges Unconstitutional?, 2007 PATENTLY-O PATENT L.J. 21 (2007). Professor Duffy later republished this brief article with an "Epilogue" detailing the response to his work by Congress and the courts. John F. Duffy, Are Administrative Patent Judges Unconstitutional?, 77 GEO. WASH. L. REV. 904 (2009).

${ }^{92}$ Intellectual Property and Communications Omnibus Reform Act of 199, Pub. L. No. 106-113, 113 Stat. 1501.
}

Pitt Tax Review | ISSN 1932-1821 (print) 1932-1996 (online) DOI 10.5195/taxreview.2014.26 | http://taxreview.law.pitt.edu 


\section{6 |Pittsburgh Tax Review | Vol. 112014}

who may constitutionally appoint inferior Officers when authorized by statute. $^{93}$ After the 1999 Act took effect on March 29, 2000, those judges were appointed by the Director of the Patent and Trademark Office (PTO) ${ }^{94}$ whose formal title is the "Under Secretary of Commerce for Intellectual Property and Director of the United States Patent and Trademark Office." ${ }^{95}$ Analogizing to the special trial judges in Freytag, who were held to be Officers due in large part to their "final decisionmaking authority," Professor Duffy concluded that administrative patent judges, who make final decisions for the PTO, are indeed Officers and must be properly appointed. ${ }^{96} \mathrm{He}$ also observed that the PTO is a mere agency within the Department of Commerce, and so the PTO Director is not a Department Head who may properly appoint Officers when authorized by statute. $^{97}$ Therefore, every administrative patent judge who was appointed since March 29, 2000 was improperly appointed and acting ultra vires. ${ }^{98}$

On August 12, 2008, long before the courts could resolve the argument first-raised by Professor Duffy, Congress stepped in to pass legislation that re-vested the authority to appoint administrative patent judges in the Secretary of Commerce. ${ }^{99}$ Congress's quick response, and the retroactive nature of the law, is widely and rightly seen as a vindication of Professor Duffy's position. Moreover, the Tucker decisions are arguably an outgrowth of the "Duffy Defect."

${ }^{93}$ Duffy, supra note 91 , at 914.

${ }^{94} I d$. at $904,912$.

${ }^{95} 35$ U.S.C. § 3(a) (2012) (emphasis added).

${ }^{96}$ Duffy, supra note 91 , at 906-07.

${ }^{97}$ Id. at $910-11$.

${ }^{98} I d$. at $911-12$.

${ }^{99}$ Carlton Smith is a former law clerk to Judge Arthur L. Nims of the U.S. Tax Court and a Clinical Associate Professor of Law at Benjamin N. Cardozo School of Law of Yeshiva University. Carlton Smith, CARDOZO.YU.EDU, http://www.cardozo.yu.edu/directory/carlton-smith.

${ }^{100}$ Carlton Smith, Tucker v. Commissioner, Petitioner's Reply Supplemental Memorandum of Law, filed Mar. 23, 2009, at 10 n.13. See also Lindstedt, supra note 8, at 1144 ("The impact of Duffy's article reached courtrooms as well, prompting an Appointments Clause challenge in Tucker v. Commissioner.").

${ }^{101}$ Smith, supra note 100 , at 10 n.13.

Pitt Tax Review | ISSN 1932-1821 (print) 1932-1996 (online) DOI 10.5195/taxreview.2014.26 | http://taxreview.law.pitt.edu 
decided to take the case of Tucker $v$. Commissioner as pro bono counsel, he was very much aware of the "Duffy Defect" and Professor Duffy's work in the patent context. ${ }^{102}$ In fact, Professor Smith credited Professor Duffy with inspiring his Appointments Clause argument in the tax context. ${ }^{103}$ Specifically, he alleged that IRS hearing officers wield "significant authority" without appointment by a Department Head. ${ }^{104}$

\section{Recent Scholarship on Tucker and the Appointments Clause}

Recent scholarship on the constitutional line between Officers and employees typically cites back to the "Duffy Defect" as its source and inspiration. ${ }^{105}$ In general, it disagrees with the outcome of the Tucker decisions, which hold that IRS hearing officers are mere employees. ${ }^{106}$ In his briefs and concurrent publications, Professor Smith argued that IRS hearing officers are Officers under the Appointments Clause because they are most analogous to the Tax Court special trial judges who were held to be Officers in Freytag.

Professor Stacey Lindstedt ${ }^{107}$ authored the most recent law review article in this area-after Tucker I was decided but prior to Tucker II. ${ }^{108}$

${ }^{102} I d$.

${ }^{103}$ Id. ("A New York Times article about the defect in the appointment of the patent and trademark judges by a person who was not the Head of a Department was the trigger that got petitioner's counsel thinking about whether CDP hearing officer needed to be appointed.").

${ }^{104}$ Tucker, 135 T.C. at 117.

${ }^{105}$ Lindstedt, supra note 8, at 1144 (“a series of articles followed 'The Duffy Defect,' questioning the applicability of the Appointments Clause to a range of government actors, from Bankruptcy Judges to the Pay Czar") (citing Harold C. Wegner, The Duffy Defect, IP Frontline IP \& TECH. MaG. (Apr. 16, 2008), http://www.ipfrontline.com/depts/article.aspx?id=18519\&deptid=4; Tuan Samahon, Are Bankruptcy Judges Unconstitutional? An Appointments Clause Challenge, 60 HaSTINGS L.J. 233 (2008); Michael W. McConnell, The Pay Czar Is Unconstitutional, WALL ST. J., Oct. 30, 2009, at A25; Steven D. Schwinn, Do White House Czars Violate the Appointments Clause?, Constitutional L. PROF. BlOG (Oct. 7, 2009), http://lawprofessors.typepad.com/conlaw/2009/10/do-white-house-czarsviolate-the-appointments-clause.html).

${ }^{106}$ See supra note 8 and accompanying text.

107 Attorneys and Paralegals, Stacy Lindstedt, http://www.oppenheimer.com/Attorneys/Detail .aspx?id=1880 (Stacey Lindstedt is a former law clerk to Judge Mark V. Holmes of the Tax Court and Legal Writing Instructor at the University of Minnesota Law School.).

${ }^{108}$ See generally Lindstedt, supra note 8.

Pitt Tax Review | ISSN 1932-1821 (print) 1932-1996 (online) DOI 10.5195/taxreview.2014.26 | http://taxreview.law.pitt.edu 


\section{8 |Pittsburgh Tax Review | Vol. 112014}

Therein, she argues that Tucker I was wrongly decided on two counts. ${ }^{109}$ Where the Tax Court held that the positions of IRS hearing officers are not "established by Law" or vested with "significant authority," Professor Lindstedt concludes the opposite. ${ }^{110}$

First, Professor Lindstedt argues that "established by Law" is best read as meaning "set forth by some legal authority," not created by statute or even regulation. ${ }^{111}$ Since the position of IRS hearing officer is lawfully created by IRS practice and procedure, ${ }^{112}$ she concludes it is "established by Law." Second, Professor Lindstedt argues that "final decision-making authority" is unnecessary for "significant authority," and that the definition of finality as the "last word" in an agency is too narrow. ${ }^{114}$ Instead, "a better test of finality" is "an action which is necessary and sufficient for judicial review." 115 Since some decisions of IRS hearing officers trigger judicial review, she finds that they possess final decision-making authority, and thus, significant authority. ${ }^{116}$ As a result, Professor Lindstedt concludes that IRS hearing officers are indeed Officers under the Appointments Clause. ${ }^{117}$

In addition to her technical, legal critique of Tucker I, Professor Lindstedt also attacks the decision for undermining the purposes of the Appointments Clause - namely, political accountability and separation of powers. ${ }^{118}$ This Article agrees with Professor Lindstedt, and the OLC Memo to which she cites, that any lawful Office, including that of IRS

\footnotetext{
${ }^{109}$ Id. at $1177-86$.

${ }^{110} I d$.

${ }^{111}$ Id. at $1177-78$.

112 “[T]he Office of Appeals personnel who were involved in Mr. Tucker's case were all hired by the Commissioner pursuant to section 7804(a)." Tucker, 135 T.C. at 119. In relevant part, section 7804 provides that "the Commissioner of Internal Revenue is authorized to employ such number of persons as the Commissioner deems proper for the administration and enforcement of the internal revenue laws. ...” I.R.C. § 7804(a).

${ }^{113}$ Lindstedt, supra note 8, at 1177-84.

${ }^{114}$ Id. at $1178-79$.

${ }^{115} I d$.

${ }^{116}$ Id. at $1183-85$.

${ }^{117}$ Id. at 1185 .

${ }^{118}$ Id. at $1184-89$.
}

Pitt Tax Review | ISSN 1932-1821 (print) 1932-1996 (online) DOI 10.5195/taxreview.2014.26 | http://taxreview.law.pitt.edu 
hearing officer, is "established by Law."119 However, this Article respectfully disagrees with Professor Lindstedt and Professor Smith on the ultimate issue. IRS hearing officers lack significant authority and are not Officers. In fact, holding otherwise would undermine the purposes of the Appointments Clause. If low-level bureaucrats must be appointed like judges, then the scrutiny and standards for all appointments will fall. As a result, the outcome of the Tucker decisions is not only legally, but normatively correct.

\section{THe POST-TUCKER DEFINITION OF OFFICER}

This Article is the first scholarly attempt to outline the post-Tucker doctrine of the Appointments Clause. As a result, it is the first to state the post-Tucker definition of "Officer."

\section{A. The Tucker Decisions}

In Tucker I, the Tax Court defines an Officer under the Appointments Clause as one who holds a position that is (1) "established by Law," (2) "continuing," and (3) vested with "significant authority." In Tucker II, the D.C. Circuit identifies three "main criteria" for determining when a position is vested with "significant authority": (1) power over "significant" or important matters, (2) "discretion," and (3) "final" decision-making authority.

No modern cases state that significant authority is possible without significance or discretion. ${ }^{120}$ However, some dicta suggest that final decision-making authority is not always necessary for a finding of significant authority. Although Tucker II is silent on the question of whether each of these "main criteria" are necessary to find "significant authority," whenever a court holds that one of the three "main criteria" is

${ }^{119} \mathrm{Id}$. at 1177 (citing Officers of the United States within the Meaning of the Appointments Clause, 2007 OLC LEXIS 3 at*120 (2007) [hereinafter Officers of the U.S.]). Dicta from Tucker II also suggests that Professor Lindstedt's formulation of "established by Law" is correct.

${ }^{120}$ Although the OLC Memo concedes that "Buckley is sometimes read to hold that persons who [lack discretion] cannot themselves be considered officers," it nonetheless insists that " independent discretion' is not a necessary attribute of delegated sovereign authority." Officers of the U.S., 2007 OLC LEXIS 3* at 53-54.

Pitt Tax Review | ISSN 1932-1821 (print) 1932-1996 (online) DOI 10.5195/taxreview.2014.26 | http://taxreview.law.pitt.edu 


\section{0 | Pittsburgh Tax Review | Vol. 112014}

absent, it also holds that "significant authority" is absent. Notwithstanding dicta to the contrary, ${ }^{121}$ or the possibility of an extreme case, this Article submits that each of the "main criteria" is a necessary element of significant authority in all or most cases.

1. Tucker I: Clarifying Modern Appointments Clause Jurisprudence in Defining an "Officer"

\section{a. Facts}

As with so many modern Greek tragedies, the tale of Larry Tucker begins with student loans and a bad economy. ${ }^{122}$ Mr. Tucker was a paralegal in the mid-1990s. ${ }^{123}$ He personally witnessed the rise of the internet and wanted to ride its proverbial wave, so he enrolled at New York University for an advanced degree in information technology. ${ }^{124}$ Unfortunately for Mr. Tucker, he graduated in 1999, right when the technology bubble burst. ${ }^{125}$ Unable to find steady work, Mr. Tucker transferred $\$ 44,700$ into an E-Trade account and engaged in volatile day trading. ${ }^{26}$ With no experience in the stock market, Mr. Tucker lost more than half of his money, and consumed the remainder for personal expenses. $^{127}$

Broke and unemployed, Mr. Tucker continued to file his tax returns, but failed to pay any of the taxes shown on them. ${ }^{128}$ On May 22, 2004, the IRS sent Mr. Tucker a "Notice of Federal Tax Lien Filing and Your Right

${ }^{121}$ In Freytag, the U.S. Supreme Court suggested that significant enough "duties and discretion" might outweigh a "lack of authority to enter a final decision." However, the Supreme Court did not decide the issue, because it found that special trial judges possess final decision-making authority. 501 U.S. at 881 .

\footnotetext{
${ }^{122}$ Tucker, 135 T.C. at 117-19; Smith, supra note 8, at 777.

${ }^{123}$ Smith, supra note 8 , at 777 .

${ }^{124} \mathrm{Id}$.

${ }^{125} I d$.

${ }^{126} I d$.

${ }^{127} \mathrm{Id}$.

${ }^{128} I d$.
}

Pitt Tax Review | ISSN 1932-1821 (print) 1932-1996 (online) DOI 10.5195/taxreview.2014.26 | http://taxreview.law.pitt.edu 
to a Hearing" for tax years 2000, 2001, and 2002. ${ }^{129}$ In response, Mr. Tucker requested a collection due process (CDP) hearing, which was held as a telephone conference between himself, his counsel, and an IRS settlement officer. ${ }^{130}$

After some correspondence, Mr. Tucker sent a Form 656, "Offer in Compromise" (OIC), to the IRS which proposed to settle approximately $\$ 39,000$ of his liabilities for $\$ 36,772$ in 116 monthly installments of $\$ 317$. $^{131}$ The settlement officer rejected the OIC and her decision was approved by her appeals team manager, a position tasked with overseeing CDP hearings. ${ }^{132}$ In response, Mr. Tucker filed his petition in U.S. Tax Court. The case was remanded to the Office of Appeals for further consideration, and once again, Mr. Tucker's OIC was rejected by a second settlement officer. ${ }^{133}$ That rejection was approved by the same appeals team manager. ${ }^{134}$ The case then returned to the Tax Court, where Mr. Tucker argued that (1) the IRS abused its discretion in rejecting his OIC and (2) the denizens of the Office of Appeals who presided over his CDP hearing were unconstitutionally appointed Officers of the United States. ${ }^{135}$

\section{b. Abuse of Discretion}

The Tax Court quickly dispensed with Mr. Tucker's argument that the IRS abused its discretion in rejecting his OIC on two grounds. ${ }^{136}$ First, the IRS was justified in rejecting the OIC because Mr. Tucker wrongfully dissipated thousands of dollars through day trading. ${ }^{137}$ Second, dissipation aside, there was a reasonable basis for the settlement officer's

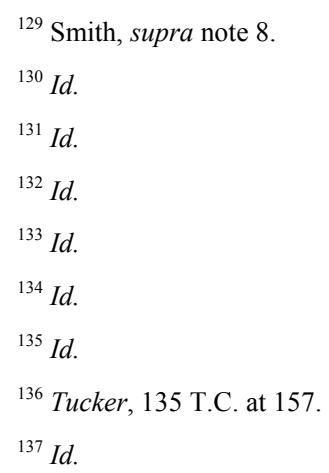

Pitt Tax Review | ISSN 1932-1821 (print) 1932-1996 (online) DOI 10.5195/taxreview.2014.26 | http://taxreview.law.pitt.edu 


\section{Pittsburgh Tax Review | Vol. 112014}

determination. ${ }^{138}$ Of greater interest was the Tax Court's nearly 90-page opinion addressing Mr. Tucker's constitutional argument that settlement officers and appeals officers who hear CDP cases, as well as the appeals team managers who supervise them, wield the significant authority of an Officer and must be installed pursuant to the Appointments Clause. ${ }^{139}$

\section{c. Definition of Officer}

The constitutional question squarely in front of the Tax Court was the status of the settlement officers, appeals officers, and appeals team managers under the Appointments Clause. To determine if these positions are that of Officers or employees, the court drew directly on the text of the Appointments Clause and Supreme Court precedent to articulate a threepart test. Namely, an Officer under the Appointments Clause holds a position that is (1) "established by Law," (2) "continuing," and (3) vested with "significant authority.",

In Tucker I, the IRS conceded that the positions at issue were "continuing." "141 However, the Tax Court held that the positions were not "established by Law" or vested with "significant authority." 142 As a result of failing two of the three prongs of the test, the Tax Court held that IRS hearing officers are mere employees. ${ }^{143}$

\footnotetext{
${ }^{138} I d$.

${ }^{139}$ See generally Tucker, 135 T.C. 114.

${ }^{140}$ Tucker, 135 T.C. at $152-60$.

${ }^{141} I d$. at 160 ("[The IRS] concedes that, if the CDP 'appeals officer' is a position 'established by Law,' then it is a 'continuing' position").

${ }^{142}$ Id. at 165 ("An 'officer or employee' of the IRS Office of Appeals who conducts CDP hearings has neither a position 'established by Law' nor 'significant authority' that is characteristic of an 'officer of the United States' for purposes of the Appointments Clause.").

${ }^{143} I d$. at $165-66$.
}

Pitt Tax Review | ISSN 1932-1821 (print) 1932-1996 (online) DOI 10.5195/taxreview.2014.26 | http://taxreview.law.pitt.edu 


\section{i. Established by Law}

A position must be "established by Law" in order to constitute an Office. ${ }^{144}$ This Article submits that any lawful Office is "established by Law" irrespective of whether such Office is created by statute or regulation.

The requirement that an Office is "established by Law" is derived directly from the text of the Appointments Clause, which provides that Offices "shall be established by Law." 145 Courts and commentators alike have debated the meaning of this phrase and at least three schools of thought have developed. The most stringent view is that a position is "established by Law" if and only if Congress adopts a statute which creates the position. ${ }^{146}$ Another somewhat more forgiving view is that a position is also "established by Law" if a valid regulation creates it. ${ }^{147}$ The most expansive viewpoint is that any lawful position, that is, any position "set forth by some legal authority," is "established by Law."148 This Article agrees with the OLC Memo, Professor Lindsedt, and dicta from Tucker II, that the third and most expansive viewpoint is correct. No other view is consistent with the underlying purposes of the Appointments Clause.

In Tucker I, the Tax Court applied the first two views to conclude that the positions of settlement officer, appeals officer, and appeals team manager were neither established by statute, nor by regulation. The only

${ }^{144}$ See U.S. CONST. art. II, § 2, cl. 2; Tucker, 135 T.C. at 152.

${ }^{145}$ See U.S. CONST. art. II, § 2, cl. 2.

${ }^{146}$ In Tucker I, the Tax Court first analyzed whether the positions of settlement officers, appeals officers, and appeals team managers were established by statute. Tucker, 135 T.C. at 152-56.

${ }^{147}$ Several Courts of Appeals have held that positions established by regulation were Offices, implying that an Office established by regulation is indeed "established by Law." Willy v. Admin. Review Bd., 423 F.3d 483, 491 (5th Cir. 2005) (finding that the members of the Administrative Review Board of the U.S. Department of Labor, positions created not by statute but by regulation, are inferior Officers); Varnadore v. Sec. of Labor, 141 F.3d 625, 631 (6th Cir. 1998) (same); Holtzclaw v. Sec. of Labor, 172 F.3d 872 (6th Cir. 1999) (same); Pennsylvania v. United States Dep't of Health \& Human Servs., 80 F.3d 796, 800 (3d Cir. 1996) (finding that members of the Appeals Board of the Department of Health and Human Services, positions created not by statute but by regulation, are inferior Officers). Moreover, in dissent, Justice Breyer has explicitly stated that the Supreme Court permits an Office to be "created either by 'regulations' or by 'statute." Free Enter. Fund v. Pub. Co. Accounting Oversight Bd., 177 L. Ed. 2d 706, 752 (U.S. 2010) (citing Mouat, 124 U.S. at 307-08).

${ }^{148}$ Lindstedt, supra note 8, at 1177 (citing OLC Memo at 120).

Pitt Tax Review | ISSN 1932-1821 (print) 1932-1996 (online) DOI 10.5195/taxreview.2014.26 | http://taxreview.law.pitt.edu 


\section{4 | Pittsburgh Tax Review | Vol. 112014}

statutory reference to appeals officers is present in sections 6320 and 6330 of the Internal Revenue Code, which were both introduced into law by the Internal Revenue Service Restructuring and Reform Act of 1998. ${ }^{149}$ The position of appeals officer already existed as of 1998, and so the position was not created by the 1998 Act. Likewise, no regulation created the positions within the Office of Appeals. As a result, the Tax Court held that none of the positions at issue were "established by Law."150

The Tax Court rejected the notion that any lawful Office is "established by Law," because "it risks reading out of the Constitution the phrase "established by Law." "151 However, it recognized the potential for abusing a narrower conception of the requirement to skirt the Appointments Clause. If only positions created by statute or regulation may be Offices, then Congress could simply vest a preexisting position, not so created, with additional powers. By way of an extreme example, Congress could vest the position of janitor with the powers of judge or attorney general. If that cosmically powerful janitor is not an Officer, then Congress would be free to provide for her appointment in any way like any other employee. It could even violate the separation of powers by appointing that janitor itself. This would be tantamount to Congress creating and filling the same position, just like King George III unleashing his tax collectors in colonial times. ${ }^{152}$ In this type of case, the Tax Court ceded that "the courts would have to see through the subterfuge and enforce the Appointments Clause."153

However, the OLC Memo goes further still. It insists that "the rule for which sorts of positions have been "established by Law' ... cannot be whether a position was formally and directly created as an 'office' by law" because "[s]uch a view would conflict with the substantive requirements of the Appointments Clause." ${ }^{154}$ In Tucker II, the D.C. Circuit declined to hold

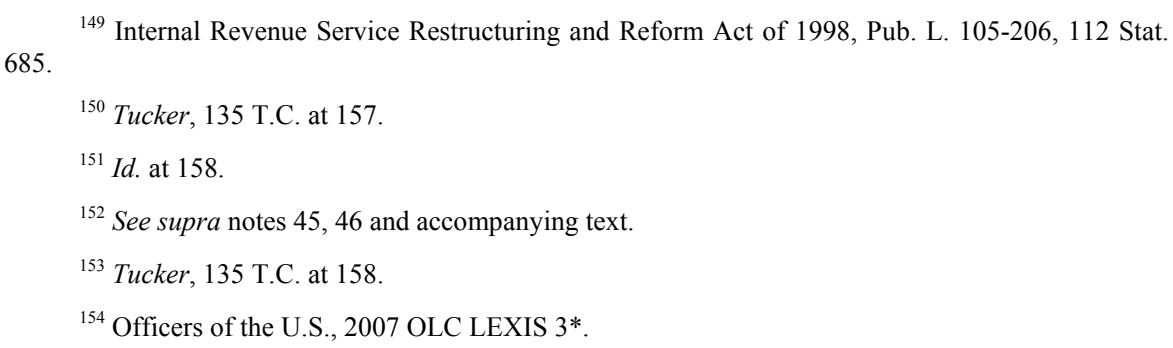

Pitt Tax Review | ISSN 1932-1821 (print) 1932-1996 (online) DOI 10.5195/taxreview.2014.26 | http://taxreview.law.pitt.edu 
whether the position of IRS hearing officers was "established by Law."155 However, in dicta, the court cited to the OLC Memo in saying "it would seem anomalous if the Appointments Clause were inapplicable to positions extant in the bureaucratic hierarchy, and to which Congress assigned 'significant authority,' merely because neither Congress nor the executive branch had formally created the positions." contends that "[a] more workable definition reads 'established by Law' to mean ... set forth by some legal authority." 157 This Article concurs with the OLC Memo, D.C. Circuit, and Professor Lindsedt that a narrower interpretation of the phrase "established by Law" would allow Congress to skirt the Appointments Clause and violate the separation of powers. As such, it concurs that any lawful Office is "established by Law." However, a position is most clearly "established by Law" when it is created by statute. $^{158}$

\section{ii. Continuing}

A position must be "continuing" in order to constitute an Office. A position is "continuing" if it is vested with "tenure, duration, emolument, and duties" which are "continuing and permanent, not occasional or temporary." 159 "A position is most clearly 'continuing' if it is permanently assigned sovereign authority that does not expire, inter alia, upon the passage of time or the completion of a discrete task."160

The requirement that an Office is "continuing" has its roots in the Constitution, which "refers to an office as something that one 'holds' and

\footnotetext{
${ }^{155}$ Tucker, 676 F.3d at 1133.

${ }^{156} \mathrm{Id}$.

${ }^{157}$ Lindstedt, supra note 8, at 1177.

${ }^{158}$ See Tucker, 135 T.C. at 152-53 (quoting Landry, 204 F.3d at 1133; Freytag, 501 U.S. at 881.) ("Where 'the "duties, salary, and means of appointment" for the office were specified by statute,' that is considered 'a factor that has proved relevant in the [Supreme] Court's Appointments Clause jurisprudence."”).

${ }^{159}$ Auffmordt, 137 U.S. at 327 (Germaine, 99 U.S. at 511-12 (quoting United States v. Hartwell, 73 U.S. 385,393 (1868)).

${ }^{160}$ Tucker, 135 T.C. at 160 (citing Auffmordt, 137 U.S. at 326-28; Germaine, 99 U.S. at 511-12; Hartwell, 73 U.S. at 393).
}

Pitt Tax Review | ISSN 1932-1821 (print) 1932-1996 (online) DOI 10.5195/taxreview.2014.26 | http://taxreview.law.pitt.edu 
'enjoys' and in which one 'continues' ...."161 Early precedent also reinforces the understanding that a position must have some duration or ongoing duties to constitute an Office. ${ }^{162}$ As far back as George Washington, our Presidents have appointed temporary diplomats without nominating them to the Senate. ${ }^{163}$ "In a striking early illustration, President Jefferson appointed Senator Daniel Smith as a commissioner to negotiate and execute treaties with the Cherokee Indians, yet Jefferson did not submit the nomination to the Senate, and Smith did not vacate his seat in the Senate." 164 Given that none of the Founders or their contemporaries objected to this early and pervasive practice, it stands to reason that it was considered constitutional. ${ }^{165}$ From a survey of the historical record, the OLC Memo concludes that the rationale for appointing temporary diplomats without following the procedures of the Appointments Clause was that those positions were not "continuing," and hence, were not Offices. ${ }^{166}$

In a trio of cases decided after the Civil War, the Supreme Court articulated, and twice reiterated verbatim, the current black letter law of the "continuing" requirement. ${ }^{167}$ In United States v. Hartwell, the first case of

${ }^{161}$ Officers of the U.S., 2007 OLC LEXIS $3 *$ at *74-75.

${ }^{162} I d$. at $* 77-78$.

${ }^{163}$ Id. at $* 79$.

${ }^{164}$ Id. at *23 (citing 1 Am. St. Papers, Indian Affairs 697-98 (1805)). As noted above, absent specific statutory authorization, the President alone may not appoint even inferior Officers without confirmation by the Senate. In addition, Article I, Section 6, Clause 2 of the Constitution, otherwise known as the Incompatibility Clause, provides that "no Person holding any Office under the United States shall be a Member of either House during his Continuance in Office." In layman's terms, Congressmen and Senators must resign their position to become Officers. The fact that President Jefferson appointed Senator Smith as a commissioner without Senate confirmation, and the fact that the Senator did not resign his seat, both strongly suggest that the position of commissioner was not an Office. This suggestion is reinforced by the fact that President Jefferson was a founding father and that no contemporaneous objections to Senator Smith's appointment are on record.

${ }^{165}$ Tucker, 135 T.C. at 126 ("Of course, the earliest Congresses and executive administrations were not infallible in their adherence to the Constitution, and their example cannot be followed uncritically; but we do properly note 'the early practice of Congress."'), quoting Free Enter. Fund, 177 L. Ed. $2 d$ at 734 .

${ }^{166}$ For a comprehensive history of the "continuing requirement," see Officers of the U.S., 2007 OLC LEXIS 3*.

${ }^{167}$ Hartwell, 73 U.S. 385; Germaine, 99 U.S. 508; Auffmordt, 137 U.S. 310.

Pitt Tax Review | ISSN 1932-1821 (print) 1932-1996 (online)

DOI 10.5195/taxreview.2014.26 | http://taxreview.law.pitt.edu 
the trilogy, the Supreme Court concluded that "a clerk in the office of the assistant treasurer of the United States, at Boston," held a "continuing" position because "[h]is duties were continuing and permanent, not occasional or temporary." 168

In United States v. Germaine, the Supreme Court followed Hartwell to conclude that a surgeon appointed by the "Commissioner of Pensions" to examine pensioners or pension claimants on an "on call" basis did not hold a "continuing" position because his "duties are not continuing and permanent, and they are occasional and intermittent." ${ }^{169}$ The Supreme Court explained that "[t]he surgeon is only to act when called on by the Commissioner of Pensions in some special case .... He may make fifty of these examinations in a year, or none." 170

Lastly, in Auffmordt v. Hedden, the Supreme Court followed both Hartwell and Germaine to conclude that a "merchant appraiser" hired by the Treasury Department for expert reappraisals of merchandise did not hold a continuing position because "[h]is position is without tenure, duration, continuing emolument, or continuous duties, and he acts only occasionally and temporarily." an executive agent, as an expert assistant to aid in ascertaining the value of the goods, selected for the particular case on the request of the importer, and selected for his special knowledge in regard to the character and value of the particular goods in question." "172 The merchant appraiser "has no claim or right to be designated, or to act except as he may be designated."173

The doctrine of the "continuing" requirement has not changed significantly since 1890 when Auffmordt was decided. There are a few close cases, like that of independent counsel, where the position is held for an indefinite time period but concludes upon the completion of a discrete

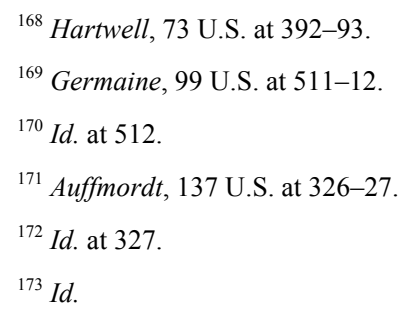

Pitt Tax Review | ISSN 1932-1821 (print) 1932-1996 (online) DOI 10.5195/taxreview.2014.26 | http://taxreview.law.pitt.edu 
task. ${ }^{174}$ However, most cases fall neatly into the category of the clearly "continuing," like the full-time, indefinitely employed special trial judges of the U.S. Tax Court, or the clearly temporary, like the special masters appointed by federal courts. ${ }^{175}$ In Tucker I, the IRS conceded that the fulltime, indefinitely employed positions of settlement officer, appeals officer, and appeals team manager are "continuing." 176

\section{iii. Significant Authority}

A position must be vested with "significant authority" in order to constitute an Office. ${ }^{177}$ Quoting the keystone of Appointments Clause jurisprudence, Buckley v. Valeo, the courts have repeatedly held that "any appointee exercising significant authority ... is an 'Officer of the United States,' and must, therefore, be appointed ...."178 It should also be noted that "Freytag calls on us to consider all the powers of the officials in question in evaluating whether their authority is 'significant,' not just those applied to the litigant bringing the challenge."179 Stated otherwise, an Officer for one purpose is an Officer for all purposes.

In Tucker I, the Tax Court echoed virtually all past courts and cases in saying " $[t]$ he Supreme Court has yet to fully define the term 'significant authority'; and 'ascertaining the test's real meaning requires a look at the roles of the employees whose status was at issue in other cases." $" 180$ In that

\footnotetext{
${ }^{174}$ In Morrison v. Olson, the Supreme Court weighed the fact that the position of "independent counsel" had "no time limit" against the fact that it "is appointed essentially to accomplish a single task, and when that task is over the office is terminated." 487 U.S. 654, 672 (1988). It ultimately concluded that "these factors relating to the "ideas of tenure, duration ... and duties' of the independent counsel," Germaine, 99 U.S. at 511, "are sufficient to establish that appellant is an 'inferior' officer in the constitutional sense." Id.

${ }^{175}$ Freytag, 501 U.S. at 881 (“[T]he duties, salary, and means of appointment for [special trial judges of the Tax Court] are specified by statute .... These characteristics distinguish special trial judges from special masters, who are hired by Article III courts on a temporary, episodic basis, whose positions are not established by law, and whose duties and functions are not delineated in a statute.")

${ }^{176}$ Tucker, 135 T.C. at 160.

${ }^{177}$ See Buckley, 424 U.S. at 126.

${ }^{178} I d$.

${ }^{179}$ Intercollegiate Broad. Sys. v. Copyright Royalty Bd., 684 F.3d 1332, 1338 (D.C. Cir. 2012) (citing Freytag, 501 U.S. at 882; Tucker, 676 F.3d at 1132).

${ }^{180}$ Tucker, 135 T.C. at 162 (quoting Landry, 204 F.3d at 1133).
}

Pitt Tax Review | ISSN 1932-1821 (print) 1932-1996 (online)

DOI 10.5195/taxreview.2014.26 | http://taxreview.law.pitt.edu 
vein, the Tax Court compared the IRS hearing officers to the special trial judges in Freytag, who were adjudicated to be Officers, and the ALJs in Landry v. FDIC, who were adjudicated to be mere employees. Ultimately, the Tax Court concluded that IRS hearing officers were more akin to ALJs than special trial judges because, like ALJs, they lacked final decisionmaking authority. ${ }^{181}$ Moreover, IRS hearing officers also lack many of the "formal powers" granted to ALJs, such as "the authority to conduct 'on the record' hearings, to require attendance at those hearings, to administer oaths and affirmations, to issue subpoenas, to rule on offers of proof and receive evidence, and to order depositions." Since the Tax Court found the reasoning of the Landry court persuasive in its determination that FDIC ALJs do not exercise significant authority, it likewise held that the "lesser position" of IRS hearing officer "does not exercise significant authority." 182 This type of comparative reasoning was the standard modality for resolving Appointments Clause cases prior to Tucker II.

\section{Tucker II: Defining "Significant Authority"}

In Tucker II, the D.C. Circuit did not disagree with the Tax Court on the facts of the case or its ultimate outcome. Like the Tax Court, it quickly dispensed with the argument that the settlement officers and appeals team manager who oversaw Mr. Tucker's case abused their discretion in rejecting his OIC. It likewise held that IRS hearing officers are mere employees, not Officers. ${ }^{183}$ However, the reasoning of the D.C. Circuit in reaching that conclusion demarks from the Tax Court's in several important respects.

First, the Tax Court held that none of the positions at issue were "established by Law" because none of them were created by statute or regulation. ${ }^{184}$ In contrast, the D.C. Circuit declined to reach the issue and implied in dicta that any lawful Office is "established by Law" irrespective

\footnotetext{
${ }^{181}$ Tucker, 135 T.C. at 164.

${ }^{182}$ Tucker, 135 T.C. at 165.

${ }^{183}$ Tucker, 676 F.3d at 1137.

${ }^{184}$ Tucker, 135 T.C. at $152-59$.
}

Pitt Tax Review | ISSN 1932-1821 (print) 1932-1996 (online) DOI 10.5195/taxreview.2014.26 | http://taxreview.law.pitt.edu 
of whether it is created by statute or regulation. ${ }^{185}$ Second, the Tax Court held that none of the positions at issue were vested with "significant authority" by analogizing to similar positions in other Appointments Clause cases. ${ }^{186}$ In contrast, the D.C. Circuit laid out a tripartite test to analyze those positions on their own merits without the need for comparison. ${ }^{187}$

Specifically, the D.C. Circuit stated that "the main criteria for drawing the line between inferior Officers and employees not covered by the clause are (1) the significance of the matters resolved by the officials, (2) the discretion they exercise in reaching their decisions, and (3) the finality of those decisions." 188 No modern case law states that significant authority is possible without significance or discretion. ${ }^{189}$ However, some dicta from the Supreme Court and D.C. Circuit suggest that final decision-making authority is not always necessary for a finding of significant authority. ${ }^{190}$

In Freytag, the Supreme Court suggested that significant enough "duties and discretion" might outweigh the lack of authority to enter a final decision. ${ }^{191}$ However, the court went on to say that irrespective of that

${ }^{185}$ Tucker, 676 F.3d at 1133 ("Nonetheless, it would seem anomalous if the Appointments Clause were inapplicable to positions extant in the bureaucratic hierarchy, and to which Congress assigned 'significant authority,' merely because neither Congress nor the executive branch had formally created the positions.").

${ }^{186}$ Tucker, 135 T.C. at 160-63 ("The Supreme Court has yet to fully define the term 'significant authority'; and 'ascertaining the test's real meaning requires a look at the roles of the employees whose status was at issue in other cases."').

${ }^{187}$ Id.

${ }^{188} I d$.

${ }^{189}$ Although the OLC Memo concedes that "Buckley is sometimes read to hold that persons who [lack discretion] cannot themselves be considered officers" it nonetheless insists that "independent discretion' is not a necessary attribute of delegated sovereign authority." Officers of the U.S., 2007 OLC LEXIS $3 *$ at *53-54.

${ }^{190}$ In addition to the cases that follow, Courts and commentators occasionally cite Edmonds for the proposition that "final decision-making authority" is not essential to "significant authority" or the definition of Officer, but rather, draws the line between inferior and principal Officers. Lindstedt, supra note 8, at 1178; see supra note 189. This interpretation of Edmonds misreads the precedent as well as the statutory authority of the judges of the Court of Criminal Appeals, which was considered in that case. Those judges, in fact, do have final decision-making authority. In some instances, their decisions are subject to a right of appeal to a higher court within the executive branch, namely, the D.C. Circuit for the Armed Forces. However, a right of appeal can hardly be said to negate finality.

${ }^{191}$ Freytag, 501 U.S. at $881-82$.

Pitt Tax Review | ISSN 1932-1821 (print) 1932-1996 (online)

DOI 10.5195/taxreview.2014.26 | http://taxreview.law.pitt.edu 
possibility, its "conclusion would be unchanged" because special trial judges may issue final decisions for the Tax Court in declaratory judgment proceedings and limited-amount tax cases under section $7443 \mathrm{~A}(\mathrm{~b})(1),(2)$, and (3), as well as subsection (c). ${ }^{192}$

In Landry v. FDIC, the D.C. Circuit also suggested that "purely recommendatory powers" were not "fatal in themselves." 193 However, in that same case, the court held that the lack of final decision-making authority was fatal to the claim that FDIC ALJs were Officers. ${ }^{194}$ In so holding, the court noted that the Supreme Court "laid exceptional stress on the [special trial judges'] final decisionmaking power" in Freytag and "that the [special trial judges'] power of final decision in certain classes of cases was critical to the Court's decision." 195

Tucker II states that "the cases are not altogether clear" and is silent on the question of whether each of these "main criteria" are necessary to find "significant authority." 196 However, an analysis of modern case law reveals that whenever a court holds that one of the three "main criteria" is absent, it also holds that "significant authority" is absent. For example, in Landry $v$. FDIC, the D.C. Circuit found that FDIC ALJs had (1) "significant" power and (2) "discretion," but (3) no "final decision-making authority" because each and every one of their cases was reviewed de novo by the FDIC Board. ${ }^{197}$ As a result, the Court held that FDIC ALJs are mere employees. ${ }^{198}$ In Tucker II, the D.C. Circuit found that the IRS hearing officers had (1) "significant" power and (2) "final decision-making authority," but (3) no "discretion." 199 As a result, the Court held that IRS hearing officers

\footnotetext{
${ }^{192} I d$.

${ }^{193}$ Landry, 204 F.3d at 1134.

${ }^{194}$ Id.; see also Tucker, 676 F.3d at 1134 ("In Landry ... we found the absence of any authority to render final decisions fatal to the claim that the administrative law judges at issue there were Officers rather than employees.").

${ }^{195}$ Landry, 204 F.3d at 1134.

${ }^{196}$ Tucker, 676 F.3d at 1133.

${ }^{197}$ Landry, 204 F.3d at 1132-34.

${ }^{198} \mathrm{Id}$.

${ }^{199}$ Tucker, 676 F.3d at 1132-35.
}

Pitt Tax Review | ISSN 1932-1821 (print) 1932-1996 (online) DOI 10.5195/taxreview.2014.26 | http://taxreview.law.pitt.edu 


\section{2 |Pittsburgh Tax Review | Vol. 112014}

are mere employees. ${ }^{200}$ Only in cases like Freytag, where the Supreme Court found all three criteria for significant authority, are the positions at issue held to be Offices. Although the courts occasionally indicate that final decision-making authority is unnecessary, none of them have actually found significant authority absent the power to make final decisions. ${ }^{201}$ Given that fact, this Article submits that each of the three "main criteria" is a necessary element of significant authority in all or most cases.

\section{a. Significant or Important Power}

One of the three "main criteria" for "significant authority" is power over significant matters. ${ }^{202}$ A matter is significant if it is "substantively significant," meaning that it is important, real, or meaningful in nature. ${ }^{203}$

Although Tucker II was light on reasoning in this respect, the requirement of "significance" appears to derive directly from the term "significant authority" and Buckley v. Valeo. If a position must be imbued with "significant authority" to constitute an Office, then it logically follows that a position vested only with insignificant authority cannot constitute an Office. Beyond logic, pragmatism requires significance. It would be a waste of time and resources to subject the selection of truly insignificant posts to the rigors of the Appointments Clause. For example, every year, the U.S. House of Representatives co-sponsors "a nationwide high school visual art competition" with the Congressional Institute. ${ }^{204}$ "Students submit entries to their representative's office, and panels of district artists select the winning entries .... The winning works are displayed for one year at the U.S.

\footnotetext{
${ }^{200} I d$.

${ }^{201}$ This Article concedes that "significant authority" without final decision-making authority is theoretically possible given the dicta in Freytag and other cases. However, the axiom, "actions speak louder than words" comes to mind. A legal framework's usefulness hinges on its ability to explain past decisions and predict future outcomes, and in every case to date, a lack of final decision-making authority has been determinative.

${ }^{202}$ Tucker, 676 F.3d at 1133.

${ }^{203}$ See id. Black's Law Dictionary equates “[i]mportance” with "significance.” BLACK's LAW DICTIONARY 824 (9th ed. 2009).

${ }^{204}$ Congressional Art Competition, U.S. House OF REPRESENTATIVES, http://www.house.gov/ content/educate/art_competition/.
}

Pitt Tax Review | ISSN 1932-1821 (print) 1932-1996 (online) DOI 10.5195/taxreview.2014.26 | http://taxreview.law.pitt.edu 
Capitol."205 Even making the unrealistic assumption that these "district artists" meet the other requirements of the Appointments Clause, it would be absurd to hold that they are Officers. The subject matter of judging a high school art competition is simply not significant or important enough to justify appointment by the President, Courts of Law, or Heads of Departments.

In Tucker II, the D.C. Circuit assumed "that the issue of a person's tax liability is substantively significant" given the Supreme Court's previous decision in Freytag that special trial judges' power over tax liability constitutes "significant authority." 206

\section{b. Discretion}

One of the three "main criteria" for "significant authority" is "discretion." 207 A position is vested with discretion when the tasks of its holder are "more than ministerial." ${ }^{208}$ Stated in the opposite, a position lacks discretion if its tasks "allowed the holder no choice ... even though the consequences of his ministerial decisions were both vital and final."209 For example, a federal executioner has no discretion. The executioner has power over significant matters-quite literally, life and death. The executioner has final decision-making authority - there is no appeal after she pulls the switch. ${ }^{210}$ However, the executioner has no discretion. The justice system tells her to execute or not, and thus, she lacks "significant authority" and is not an Officer.

The requirement of discretion derives from Freytag, ${ }^{211}$ and ultimately, Buckley v. Valeo. ${ }^{212}$ For this proposition, Tucker II cites directly to the

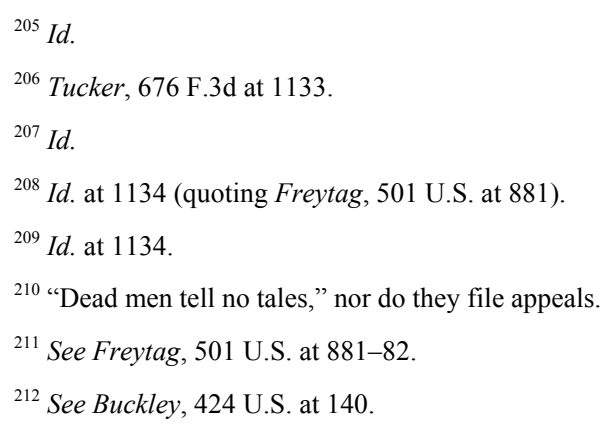

Pitt Tax Review | ISSN 1932-1821 (print) 1932-1996 (online) DOI 10.5195/taxreview.2014.26 | http://taxreview.law.pitt.edu 
Supreme Court and states "in Freytag the Court was at pains to note that the STJs' tasks were 'more than ministerial.",213 Moreover, in Freytag, the Supreme Court explicitly held that "special trial judges exercise significant discretion" in finding them Officers. ${ }^{214}$ Thus, neither the concept, nor the term of discretion was invented by the D.C. Circuit in Tucker II. ${ }^{215}$ Instead, it drew the term and its meaning in the context of the Appointments Clause directly from Freytag. ${ }^{216}$ Both "discretion" and "final decision-making authority" are aspects of "independent authority" in Freytag, and ultimately, the power to act "free from day-to-day supervision" in Buckley v. Valeo. ${ }^{217}$

In Tucker II, the D.C. Circuit held that IRS hearing officers lacked discretion, and hence, lacked significant authority. ${ }^{218}$ It reached that conclusion because that position is "subject to consultation requirements, to guidelines, and to supervision" with respect to all decisions. ${ }^{219}$ To summarize the court's reasoning, any issues that come before an IRS hearing officer are resolved without her discretion by reference to the Internal Revenue Manual, published IRS guidance, Treasury regulations, or directions from the IRS Office of Chief Counsel and other higher-ups in the Treasury Department. ${ }^{220}$ Like the executioner, the IRS hearing officer has

\footnotetext{
${ }^{213}$ Tucker, 676 F.3d at 1134 (quoting Freytag, 501 U.S. at 881).

${ }^{214}$ Freytag, 501 U.S. at 882 . In fact, the D.C. Circuit previously recognized the importance of Freytag's reference to "significant discretion" in Landry v. FDIC and labeled it "a magic phrase under the Buckley test." Landry, 204 F.3d at 1134.

${ }^{215}$ Tucker, 676 F.3d at 1134; Freytag, 501 U.S. at 881-82.

${ }^{216}$ Tucker, 676 F.3d at 1134.

${ }^{217}$ See Freytag, 501 U.S. at 881-82; Buckley, 424 U.S. at 140.

${ }^{218}$ Tucker, 676 F.3d at 1134.

${ }^{219} I d$.

220
}

[I]n reaching such decisions (and indeed in all its decisions), Appeals is subject to consultation requirements, to guidelines, and to supervision. First, the office is instructed in the Internal Revenue Manual to '[r]equest legal advice from an Associate Chief Counsel office on novel or significant issues.' I.R.M. pt. 8.6.3.5 (Oct. 26, 2007). Second, the Manual tells Appeals to seek a 'Technical Advice Memorandum' from the Chief Counsel's Office "when a lack of uniformity exists on the disposition of the issue or the issue is unusual or complex enough to warrant consideration by the Office of Chief [***12] Counsel.' Id. at pt. 8.6.3.3(3) (July 15, 2010); see also 26 C.F.R. § 601.106(f)(9)

Pitt Tax Review | ISSN 1932-1821 (print) 1932-1996 (online) DOI 10.5195/taxreview.2014.26 | http://taxreview.law.pitt.edu 
no discretion to settle a tax case or not, she simply follows the manual or her superior's instructions. ${ }^{221}$

\section{c. Final Decision-Making Authority}

One of the three "main criteria" for "significant authority" is final decision-making authority. ${ }^{222}$ There are at least three plausible schools of thought on what constitutes "final decision-making authority." First, one might argue that the case law is simply too vague to define a final decision, and perhaps the term has different meanings in different contexts. ${ }^{223}$ Second, Professor Lindsedt cites to the administrative definition of finality and argues that a final decision is better defined as "an action which is necessary and sufficient for judicial review."224 Third, this Article concurs

(The Chief Counsel is appointed by the President with the advice and consent of the Senate. 26 U.S.C. $§ 7803(b)(1)$.). Third, Appeals is required to follow any established technical or legal IRS position that is favorable to the taxpayer. I.R.M. pt. 8.6.3.5.2; 26 C.F.R. §601.106(f)(9)(viii)(c). Fourth, various regulations and the Internal Revenue Manual impose detailed guidelines for what settlements Appeals may accept. See, e.g., 26 C.F.R. §601.106(f); I.R.M. pt. 8.23.1; see also 26 U.S.C. § 7122(d)(1) (requiring the Secretary to prescribe such guidelines). Fifth, Appeals must obtain a favorable opinion from the General Counsel for the Treasury for any compromise in which the unpaid amount of tax is $\$ 50,000$ or more, and its compromises of smaller amounts are subject to 'continuing quality review by the Secretary.' I.R.C. $\S 7122(\mathrm{~b})$. The authority to provide a favorable opinion for compromises of $\$ 50,000$ or more has been delegated to the Chief Counsel and redelegated to Division Counsel, see I.R.M. pt. 33.3.2.1(3) (Nov. 4, 2010), but such delegations could be revoked at the General Counsel's discretion. Sixth, any 'closing agreement' relieving a taxpayer of liability must be approved by the Secretary. I.R.C. § 7121(b). As with the General Counsel approval, that authority has been delegated to the Commissioner, 26 C.F.R. $\S 601.202(\mathrm{a})(1)$, and redelegated to others including some Appeals employees, see Delegation Order 8-3, I.R.M. pt. 1.2.47.4 (Aug. 18, 1997) (formerly Delegation Order No. 97 (Rev. 34)); I.R.M. pt. 8.13.1.1.6 (Nov. 9, 2007), but the Secretary remains free to revoke it if he finds defects in practice under the delegations.

Tucker, 676 F.3d at 1134-35.

${ }^{221}$ Supra note 220.

${ }^{222}$ Tucker, 676 F.3d at 1133 (D.C. Cir. 2012).

${ }^{223}$ For example, what constitutes a final decision for an executive agency might differ from what constitutes a final decision for a court.

${ }^{224}$ Lindstedt, supra note 8, at 1178.

Pitt Tax Review | ISSN 1932-1821 (print) 1932-1996 (online) DOI 10.5195/taxreview.2014.26 | http://taxreview.law.pitt.edu 
with Tucker I that a final decision is the "last word" within the agency or court in question. ${ }^{225}$

A position is vested with final decision-making authority when its holder "has the final say within the agency" or court. ${ }^{226}$ In case after case, the courts have analyzed finality under the Appointments Clause in terms of the last word for the agency or court. In Freytag, the U.S. Supreme Court held that special trial judges possess "final decision-making authority" because they are authorized to make the "final decision of the Tax Court" in declaratory judgment proceedings and limited-amount tax cases. ${ }^{227}$ In Landry v. FDIC, the D.C. Circuit held that ALJs lack final decision-making authority because each and every one of their cases is subject to de novo review by the FDIC Board, and thus, they "can never render the decision of the FDIC." ${ }^{228}$ In Tucker I, the Tax Court held that IRS hearing officers lack final decision-making authority because they lack "the power to make final decisions for the IRS. ${ }^{, 229}$ In Tucker II, the D.C. Circuit reversed the Tax Court to hold that IRS hearing officers possess final decision-making authority because they have the power to make final "decisions within the executive branch., 230

In one very strong sense, equating finality with actions that trigger judicial review is attractive. That standard draws a bright line. If the decision is appealable to court, then it is final. However, outside of the

\footnotetext{
${ }^{225}$ See Tucker, 135 T.C. at $162-65$.
}

${ }^{226} I d$. (framing the issue in Tucker I as whether the positions at issue "possess the power to make final decisions for the IRS").

${ }^{227}$ Freytag, 501 U.S. at $877-82$.

${ }^{228}$ Landry, 204 F.3d at 1133-34.

${ }^{229}$ See Tucker, 135 T.C. at 162-65. In Tucker II, the D.C. Circuit held the opposite. Tucker, 676 F.3d at 1134. IRS hearing officers have final decision-making authority because they have the power to make final "decisions within the executive branch." $I d$.

${ }^{230}$ Tucker, 676 F.3d at 1134 . If anything, the D.C. Circuit stated a higher standard for finality than the Tax Court by defining finality with respect to the entire executive branch rather than one agency. Id. However, it is doubtful that the D.C. Circuit meant to propound a new rule that finality requires finality within an entire branch of government. See id. In that extreme case, one could argue that only Supreme Court decisions are final within the judicial branch. See id. However, the court offered no explanation for its conclusion that IRS hearing officers possess final decision-making authority so one is largely left to guess at its reasoning. Id.

Pitt Tax Review | ISSN 1932-1821 (print) 1932-1996 (online)

DOI 10.5195/taxreview.2014.26 | http://taxreview.law.pitt.edu 
administrative law context, this type of standard may not apply at all. ${ }^{231}$ Judges of the Tax Court issue decisions in so-called S cases which "shall not be reviewed in any court ...."232 The fact that $\mathrm{S}$ cases are not subject to appeal does not make them any less final. In fact, the Supreme Court held that the power to decide $\mathrm{S}$ cases evidenced final decision-making authority, and in effect, ensured that special trial judges are Officers. ${ }^{233}$

Equating finality in terms of finality within an agency or court has the disadvantage of being harder to determine. On occasion, it may be difficult to identify the "agency" in question. For example, in the case of IRS hearing officers, is the Office of Appeals the agency in question, or the entire IRS?

However, from Freytag to Tucker I, the courts have defined finality in terms of finality for the agency or court. It is also a metric that can theoretically apply to any case, not just those in the administrative context. Therefore, this Article concludes that a position is vested with final decision-making authority when its holder "has the final say within the agency" or court. ${ }^{234}$

\section{B. Status Quo Bias and the Appointments Clause}

Status quo bias is defined as a cognitive bias for the status quo. ${ }^{235}$ It refers to our innate, human preference for things to stay the same, even when change is positive. ${ }^{236}$ Of course, not all change is a good thing. A

\footnotetext{
${ }^{231}$ In fact, Professor Lindstedt admits that "finality may look different to an agency than it does to a court." Lindstedt, supra note 8 , at 1175 .

${ }^{232}$ The amount in controversy in cases decided under section 7463 (b) may not exceed $\$ 50,000$, so they are often referred to as S cases or small tax cases. See I.R.C. § 7463(a), (b).

${ }^{233}$ Freytag, 501 U.S. at 879.

${ }^{234}$ See Tucker, 135 T.C. at 162-65 (framing the issue in Tucker I as whether the positions at issue "possess the power to make final decisions for the IRS").

${ }^{235}$ William Samuelson and Richard Zeckhuaser are credited with coining the term "status quo bias" in 1988. William Samuelson \& Richard Zeckhauser, Status Quo Bias in Decision Making, 1 J. Risk \& Uncertainty 7 (1988). See also Deborah A. Geier, An Introduction to the U.S. FEDERAL INCOME TAXATION OF INDIVIDUALS 119 (1st ed. 2014) ("under the status quo cognitive bias, we like things to stay relatively the same, or, stated differently, we are resistant to change").

${ }^{236}$ Samuelson \& Zeckhauser, supra note 235.
}

Pitt Tax Review | ISSN 1932-1821 (print) 1932-1996 (online) DOI 10.5195/taxreview.2014.26 | http://taxreview.law.pitt.edu 


\section{8 |Pittsburgh Tax Review | Vol. 112014}

court may, quite rationally, be reluctant to upset centuries of practice or throw entire government agencies into chaos. ${ }^{237}$ Rational or otherwise, there is a heavy preference for the status quo in Appointments Clause cases, including the Tucker decisions. Findings of violations are few and far between. Although the Tax Court and D.C. Circuit disagreed on why, both of the Tucker decisions held that IRS hearing officers are mere employees and found no constitutional problem. ${ }^{238}$ Moreover, where violations are found, they are typically attributable to recent laws. In Buckley v. Valeo, the Supreme Court struck down a statute passed only a few years earlier and returned election law to the status quo. ${ }^{239}$ In the case of the infamous "Duffy Defect," Congress amended a law that was only in place for a little over eight years and returned the power to appoint administrative patent judges to the Secretary of Commerce, who held that power before the offending law was passed. Whether a violation is found or not, Appointments Clause cases tend to reinforce the status quo.

The Tucker decisions provide an objective legal framework to evaluate Appointments Clause cases. However, that framework is the construct of many moving parts and definitions, each of which is subject to some level of interpretation. The precise definitions of significance, discretion, and final decision-making authority are still debatable. In close cases, there is ample room for subjective or qualitative biases to play a role. To successfully predict outcomes, one must be cognizant of the thumb on the scale for the status quo.

\section{CONCLUSION}

For the first time, the federal courts have outlined a comprehensive legal framework to define "Officers of the United States" under the Appointments Clause. Under Tucker I, an Officer holds a position that is (1) "established by Law," (2) "continuing," and (3) vested with "significant

\footnotetext{
${ }^{237}$ In all likelihood, the pragmatic concern for efficient and effective government operations is the main driver for preferring the status quo in Appointments Clause cases. Patently ridiculous or extremely inconvenient legal outcomes are often ignored using the old rationale that "[ $\mathrm{t}] \mathrm{he}$ Constitution is not a suicide pact."

${ }^{238}$ Tucker, 676 F.3d at 1135 ; Tucker, 135 T.C. at 165-66.

${ }^{239}$ See generally Buckley, 424 U.S. 1.
}

Pitt Tax Review | ISSN 1932-1821 (print) 1932-1996 (online) DOI 10.5195/taxreview.2014.26 | http://taxreview.law.pitt.edu 
authority." Under Tucker II, "significant authority" consists of three "main criteria": (1) power over "significant" or important matters, (2) "discretion," and (3) "final" decision-making authority. This Article adds the observation that each of the three criteria is a necessary element of significant authority in all or most cases.

The Tucker tests provide an objective paradigm for deciding and predicting the outcome of Appointments Clause cases. However, that paradigm has a lot of moving parts, each of which is subject to interpretation. In close cases, where more than one interpretation is possible, it is critical to understand that courts have a heavy preference for the status quo. Perhaps that preference is due to status quo bias or a rational desire to avoid upsetting the federal applecart. Either way, litigants and commentators repeatedly admonish the courts to apply the Appointments Clause more vigorously. In particular, the Tucker decisions are criticized for threatening the political accountability of positions in the IRS, and ultimately, the separation of powers. ${ }^{240}$

However, courts should be very wary of overusing the Appointments Clause. If every single ALJ, low-level IRS bureaucrat, and countless equivalent positions in the federal government are held to constitute Offices which require appointment, the end result is all too predictable. The President, Courts of Law, and Heads of Departments will happily fire up their autopens and appoint every single position in the federal government. In the case of low-level positions, nothing is gained. Regardless of their status under the Appointments Clause, the Secretary of the Treasury will never personally interview IRS hearing officers. Each one will receive a certificate of appointment suitable for framing, but otherwise, their selection process remains the same. This charade would be useless, but not without cost. Higher-level positions, like special trial judge, independent counsel, or assistant attorney general, are liable to be lost in the shuffle of thousands or even millions of meaningless appointments. Ironically enough, overzealous application of the Appointments Clause is just as dangerous as

${ }^{240}$ Lindstedt, supra note 8 , at $1187-89$.

Pitt Tax Review | ISSN 1932-1821 (print) 1932-1996 (online) DOI 10.5195/taxreview.2014.26 | http://taxreview.law.pitt.edu 


\section{0 | Pittsburgh Tax Review | Vol. 112014}

ignoring it altogether. Appointing everyone is tantamount to appointing no one. $^{241}$

${ }^{241}$ Tens of thousands of nominations for military office are sent to the Senate each year, and they receive little or no scrutiny. See Weiss v. United States, 510 U.S. 163, 191 n.6 ("Senate confirmation of military and naval officers has become for all practical purposes an empty formality") (quoting JOSEPH P. HARRIS, THE AdVICE AND CONSENT OF THE SENATE 331 (1953)). See also Lindstedt, supra note 8, at $1186-87$ ("our government has faced the annual appointment of roughly 240,000 military officers in the past").

Pitt Tax Review | ISSN 1932-1821 (print) 1932-1996 (online)

DOI 10.5195/taxreview.2014.26 | http://taxreview.law.pitt.edu 